\title{
Exchange Rate and Competiveness of Senegalese Companies
}

\author{
Abdou Aziz Toure 1*, Souleymane Keita ${ }^{2}$
}

Faculty of Economic and Management, Cheikh Anta Diop University, Dakar Senegal.

*Corresponding Author: Abdou Aziz Toure

\begin{abstract}
This paper aims at assessing the potential impact of the exchange rate on the competitiveness of Senegalese companies. It attempts to evaluate the elasticity of manufacturing exports in relation to public and private investment and to the real effective exchange rate in Senegal, over the period 19842010. The methodology used is an econometric model based on an equation of reduced form. The results of the long-term model estimation indicate that public and private investment both have a positive and significant impact on manufacturing exports while the real effective exchange rate has a negative impact.
\end{abstract}

Keywords: Exchange rates, Competitiveness, Elasticity of exports, Senegalese companies.

\section{Introduction}

The economic boom so hoped by the Senegalese authorities will only become reality if growth and development are carried out by sustainably competitive companies. Therefore, it is necessary to lay the foundations for this competitiveness. If the concept of competitiveness is widely used in the political and economic sphere, the term does not really have a precise definition and it can be analyzed from several angles. From a business point of view, competitiveness can be defined as an ability to produce goods or services with a favorable price-quality ratio, which will allow it to ensure good profitability while gaining market share over its competitors.

In the mid-1980s, the industrial sector showed signs of slowing. Then, after an acceleration phase between 1973 and 1978, the growth rate of the industrial sector slowed down from $4.4 \%$ to $4 \%$ between 1978 and 1987 and then fell to $3.5 \%$ between 1987 and 1990. In order to deal with these poor performances, the Senegalese public authorities in the wake of structural adjustment programs had adopted in February 1986, the New Industrial Policy (NPI), around certain major principles in particular: reducing the high level of tariff protection, removing non-tariff protection, strengthening the competitiveness of Senegalese industry, promoting high value- added products and accelerating industrial recovery. However, it should be pointed out, the abrupt shift to a policy of all-out protection under the NPI, has not enabled the industrial sector to have sufficient response capacities in the face of this situation. With the advent of program approaches from 1993, the logic of developing industrial policies and strategies has evolved with the transition from a sectoral policy for the development of industry to a horizontal policy for improving the private sector environment. This option further weakened the management of industrial policy in a specific way.

It should be added that since 1994, the year of the devaluation of the FCFA, both internal and external determinants of economic activity have undergone several changes. The beneficial effects during the post NPI period (the Industrial Production index gained more than 10 points in 2000 compared to 1993 and the growth rate at the same time went from $2.54 \%$ to more than $6 \%$ ).

They are essentially due to the mechanical effect of the change in parity of the FCFA. Between 2001 and 2004, the average growth rate of GDP in the industrial sector was around $2.79 \%$ while the Industrial Production index gained almost 40 points for the same period. However, these 
achievements remain fragile, all the more that an additional amount remains necessary to face the current challenges linked to the advent of WAEMU and the WTO. Overall, the study seeks to analyze the impact of exchange rate fluctuations on the competitiveness of Senegal's manufacturing sector. Most of the empirical work carried out in the context of Senegal is limited to analyzing the evolution of Senegal's external competitiveness in relation to its UEMOA partners and its competitors outside the franc zone [1-2].

The added value of this study is to analyze the competitiveness of Senegalese companies over the post-evaluation period (1994-2010). The methodological approach is based on a reduced form equation, linking investment expenditure and the REER to volume exports from the manufacturing sector. The results of the long-term model estimate indicate that public and private investment all have a positive and significant impact on manufacturing exports at the $10 \%$ and $5 \%$ threshold, respectively.

While the real effective exchange rate has a negative impact on manufacturing exports. In the short term, investment and the real effective exchange rate all have a significant impact on Senegal's manufacturing exports. The article is structured is as follows. Section1 discusses the literature review. Section 2 presents the methodology. Section 3 is reserved for the discussion of empirical results and the section 4 presents the conclusion.

\section{Literature Review}

International competitiveness is viewed by Krugman [3] and De Grauwe [4] as the most misunderstood concept in economics. According to Bhawsar and Chattopadhyay [5] the major problem is the abundance of definitions of in the literature. The debate on international competitiveness, which is based on a multitude of concepts, often without any explicit theoretical foundation, leaves a generally-accepted theory still missing [6].

There is, therefore, a need for a comprehensive review of the literature on international competiveness. The rare existing analyses by Chaudhuri and Ray [7], followed by Banwet et al. [8], Bhawsar and Chattopadhyay [5] have provided a critical review of the literature. They all deal with definitions, measurements and sources of the

various concepts in international competitiveness and always propose an integrated and eclectic approach, combining different schools of thought and multiple measurements as the most suitable way to study the subject. The study of the determinants of international competitiveness is linked to the evolution of theories of international trade and economic growth. Among the factors that affect competitiveness and consequently export performance, several authors have specifically investigated the role played by the following factors:

- The productivity: improvements made in terms of organization of labor, changes in the quality of production factors, a better knowledge of production processes and the efficiency of resource allocation can positively affect the productivity. In this context, productivity gains appear to be a critical determinant of the competitiveness of a given country [9].

- Customs tariffs: A Customs Tariff duty is the simplest of trade policy measures. It is a tax levied on the occasion of the import of goods. This variable are traditionally used as a source of income for governments but their true purpose is none other than protecting particular economic sector

- Exchange rate: Macroeconomic theory considers a decline in the real exchange rate (a fall in the relative price of tradable in terms of non tradable goods) boost exports and limit the effect of external constraints. From this angle, the devaluation is a powerful factor that can promote the development and international competitiveness [10]. The real exchange rate (TCR) is a theoretical concept. There are two main definitions: The first definition comes from the purchasing power parity theory, based on the notion of a given country's external TCR, i.e. nominal exchange rate adjusted for the differential between its price level and that of other countries. The second definition comes from the theory of international trade. It applies to small price-takers, the case of many developing countries. It defines the socalled internal TCR as the ratio, within the same country, of the domestic prices of 
tradable goods and those of non-tradable goods internationally. This relative price is an indicator of internal competitiveness.

In the context of Senegal, Diaw [1] studied the evolution of Senegal's external competitiveness compared to its UEMOA partners and its competitors outside the franc zone, by analyzing the evolutions of TCN, TCER and TCRB. From the comparison of the TCN and the TCER, he deduced that the overvaluation of the Senegalese currency observed was not due to the evolution of the TCN, but to the inadequacy of its level compared to the other fundamental variables. The external competitiveness position of Senegal from 1975 to 1994 , compared to Nigeria, Morocco, Tunisia and Thailand was also analyzed by Dieye [2]. He examined in addition to the evolutions of the TCRB, the modalities interventions on these rates. $\mathrm{He}$ noted that Nigeria and Ghana have changed their TCN; Morocco and Thailand acted on the level of prices and internal costs compared to the external; as for Tunisia, it combined these first two actions. For Senegal, Dieye recommends acting on the structural determinants.

\section{Section 2: Methodological Framework}

The methodological approach is inspired by the work of Chakroun [11] on the determinants of the international competitiveness of the Tunisian manufacturing sector. In its general form, the equation to be estimated is written:

\section{$\operatorname{LnEXPO}_{t}=\beta_{0}+\beta_{1} \operatorname{LnKPUT}_{t}+\boldsymbol{\beta}_{2} \operatorname{LnKPRT}_{t}+\boldsymbol{\beta}_{3} \operatorname{LnTCER}_{t}+\boldsymbol{U}_{t}$} With $\mathrm{Ln}=$ logarithme; EXPO= Manufacturing sector volume exports per worker.

KPUT= public capital per worker; KPRT= private capital per worker; TCER $=$ real effective exchange rate; $\mathrm{U}=$ error term; $\mathrm{t}=$ period; $B_{0}$ to $B_{3}$ coefficients to be estimated. Theoretically, the coefficients B_1 and B_2 should be positive, expressing the fact that an increase in the stock of public capital or private capital per worker makes it possible to produce more and therefore and to export more.

On the other hand, the coefficient $8 \_3$ should be negative, which means that the appreciation of the real effective exchange rate leads to a loss of competitiveness in manufacturing exports. The data used are annual data covering the period from 1984 to 2010. Our data sources are: the database of social indicators of Senegal (BADIS) of ANSD and the direction of forecast and economic studies (DPEE).

We used manufacturing exports as an indicator of competitiveness. This variable allows us to measure the capacity of the Senegalese manufacturing sector to sell its products outside. It is measured by the ratio between the sector's volume exports and the number of employees. Three exogenous variables are retained in Our study:

The Stock of Public Capital per Worker (KPUT)
This variable is measured by the ratio between gross fixed capital formation in the public sector and the total number of employees in the manufacturing sector. It is used as a determinant of export competitiveness.

\section{The Stock of Private Capital per Worker (KPRT)}

As the previous variable, the private capital stock per worker is measured by the ratio between the gross formation of private fixed capital and the total number of employees in the manufacturing sector. It is used as a determinant of export competitiveness.

\section{The Real Effective Exchange Rate (TCER)}

This variable is measured by the weighted average of bilateral exchange rates between Senegal and its main trading partners. It is used as a determinant of export competitiveness. We chose 1994 as the base year for the TCER series on the assumption that the devaluation brought the exchange rate back to its equilibrium value.

\section{Section 3: Results and Discussions}

\section{The Long Term Model}

The long-term relationship of our econometric model is as follows: 
Table 1: long-term relationship estimation results

\begin{tabular}{|c|c|c|c|}
\hline \multicolumn{3}{|c|}{ Dependent variable: Ln EXPO } & Prob \\
\hline Ln EXPO & Coef & t-stat & 0.063 \\
\hline Ln KPUT & $0.721^{*}$ & 1.950 & 0.276 \\
\hline Ln KPRT & $0.409^{* *}$ & 1.116 & 0.063 \\
\hline Ln TCER & $-1.042^{* *}$ & -1.954 & 0.0044 \\
\hline Constant & 9.589 & 3.162 & \\
\hline
\end{tabular}

*** (signification a $1 \%) ; * *$ (significatif a $5 \%) *($ significatif a $10 \%)$

The results of the long-term model estimate indicate that public investment and private investment all have a positive and significant impact on manufacturing exports at the $10 \%$ and 5\% threshold respectively. In accordance with previous studies, the coefficients associated with the variables: public capital per capita (0.720) and private capital per capita (0.409), which measure the long-term elasticities of manufacturing exports in relation to public and private investment are both positive and significant at $10 \%$ and $5 \%$ respectively. The coefficient associated with the variable real effective exchange rate (0.142 ) is negative and significant at $5 \%$.
These coefficients indicate that any increase in public or private investment in the Senegalese manufacturing sector offers new opportunities for competitiveness for industrialists, while the appreciation of the exchange rate reduces their flexibility.

\section{The Short-Term Model}

As indicated above, to estimate the shortterm relationship, we used the residue from the estimation of the long-term relationship after testing its stationarity as the error correction term. Thus, the short term relationship estimates is written as follows:

\section{$\boldsymbol{D}\left(\operatorname{LnEXPO}_{t}\right)=\lambda_{0}+\lambda_{1} D\left(\operatorname{LnKPUT}_{t}\right)+\lambda_{2} D\left(\operatorname{LnKPRT}_{t}\right)+\lambda_{3} \boldsymbol{D}\left(\operatorname{LnTCER}_{t}\right)$$$
+\lambda_{4} R_{E S I} I_{t-1}+V_{t}
$$

$\mathrm{D}$ is the first difference operator; RESI is the residue of the long-term model estimate and Vt the error term. Theoretically, the coefficient $\lambda \_4$ must be negative and significant, otherwise there is no error correction mechanism and therefore the MCE is not valid.

Table 2: Result of the estimation of the short-term relationship

\begin{tabular}{|c|c|c|c|}
\hline \multicolumn{2}{|c|}{ Dependent: Ln EXPO } & Prob \\
\hline Ln KPUT & Coef & -0.449 & 0.657 \\
\hline Ln KPRT & $-0.099^{*}$ & 1.6197 & 0.120 \\
\hline Ln TCER & $0.398^{* *}$ & -1.4599 & 0.159 \\
\hline RESI & $-0.833^{* * *}$ & -2.509 & 0.020 \\
\hline Constant & $-0.422^{* *}$ & 1.441 & 0.164 \\
\hline \multicolumn{2}{|c|}{$\mathrm{R}^{2}=0.288 ; \mathrm{Ra}^{2}=0.152 ; \mathrm{DW}=1.723 ;$ F-stat $=2.1197 ;$ Prob(F-stat) $=0.114$} \\
\hline
\end{tabular}

As in the long term, the coefficients of the short term model are all significant. This means that in the short term, investment and the real effective exchange rate all have a significant impact on Senegal's manufacturing exports. According to economic theory, the impact of public and private investment are positive and significant at the $5 \%$ threshold, while that of the exchange rate is negative and significant at the $1 \%$ threshold. However, it should be noted that the coefficients of the variables: public capital per capita (0.099) and private capital per capita $(0.398)$ are lower compared to the long-term model where the coefficients are 0.720 and 0.409 respectively. While the coefficient on the variable real effective exchange rate $(-0.833)$ is higher in absolute value compared to the long-term model ($0.142)$.

\section{Conclusion}

This work is devoted to studying the impact of the exchange rate on the competitiveness of companies in Senegal's manufacturing sector. Research results show that over the 1984-2010 periods, public investment and private investment were favorable to 
improving the competitiveness of Senegal's manufacturing exports, while the instability of the real effective exchange rate constituted a handicap for exports. The results suggest

\section{References}

1. Diaw A (1997) Politique macroéconomique et compétitivité de l'économie sénégalaise, in journées scientifiques du CREA sur l'économie sénégalaise.

2. Dieye A (1996) La compétitivité de l'économie sénégalaise, Thèse de doctorat nouveau régime, Université d'Auvergne, Faculté des Sciences Economiques, CERDI.

3. Krugman PR (1994) Competitiveness - A dangerous obsession. Foreign Affairs 73(2/March/April): 28-44.

4. De Grauwe P (2010) Introduction. In P. De Grauwe (Eds.) Dimensions of Competitiveness. Cambridge: MIT Press

5. Bhawsar P, Chattopadhyay U (2015) Competitiveness: Review, Reflections and Directions. Global Business Review 16(4): 665-679.

6. Lachmann W (2001) Improving the international competitiveness of nations. WEP Working 6: 1-21. that Senegal could, in the long term, improve the competitiveness of its manufacturing sector by adopting exchange and investment policies compatible with this objective.

7. Chaudhuri S, Ray S (1997) the competitiveness conundrum literature review and reflections. Economics and Political Weekly 32(48): 83-91.

8. Banwet DK, Momaya K, Shee HK (2002) Competitiveness: Perceptions, reflections and directions. IIMB Management Review 14(3/May): 105-116.

9. Parienty A (2013) Les déterminants de la compétitivité. Alternatives Economiques, (329). Retrieved from http://s182403251.onlinehome.fr/spip.php? article

10. Boltho A (1998) Convergence, Competitiveness and the Exchange Rate. In N. Crafts, \& G. Toniolo (Eds.), Post War European Economic Growth (107-30).

11. Chakroun M (2002) Les déterminants de la compétitivité internationale du secteur manufacturier Tunisien: Un modèle. Retrieved from http://www.instituteuroplace.com 